\title{
Growing together: A principle-based approach to building collaborative Indigenous partnerships in Canada's forest sector
}

\author{
by Paul A. Robitaille, ${ }^{1,}$ " Chander Shahi, ${ }^{2}$ M.A. (Peggy) Smith ${ }^{1}$ and Nancy Luckai ${ }^{3}$
}

\begin{abstract}
While a great deal of recent research has focused on opportunities for Indigenous participation in Canada's forest sector, relatively little has explored how to translate various lessons learned into inclusive and mutually-beneficial collaborative processes. Through a review of recent peer-reviewed literature examining Indigenous participation in forest management and development, this paper seeks to fill the current knowledge gap by proposing a set of five principles, with twentythree underlying supporting mechanisms, that can be adopted by Indigenous communities, resource managers and government policy makers to help facilitate meaningful collaboration within the forest sector. These principles include: building respectful relationships; broad community engagement; bridging knowledge and value systems; flexible and holistic management systems; and clear and relevant measures of success. Although the proposed principles may be implemented either individually or in various combinations, to both improve existing collaborative arrangements and develop new ones, they may be best conceptualized as an integrated, incremental process involving any number of motivated partners. It is hoped that the lessons presented in this article will serve as a basis for diverse stakeholder groups to better understand each other's needs and ultimately work more effectively towards achieving respectful co-existence and equity in Canada’s forest sector.
\end{abstract}

Key Words: Aboriginal, collaboration, development, First Nation, forest, Indigenous, management, natural resource, partnership, planning

\section{RÉSUMÉ}

Bien qu'une grande partie des recherches récentes ait porté sur les occasions de participation pour les peuples Autochtones dans le secteur forestier, relativement peu de travaux se sont penchés sur les façons d’appliquer les différents enseignements retenus dans des processus de collaboration inclusifs et mutuellement profitables. En sappuyant sur une analyse des documents scientifiques récents sur la participation des Autochtones à l'aménagement et au développement forestier, cet article cherche à combler le manque actuel de connaissances en proposant un ensemble de cinq principes, accompagnés de 23 mécanismes de base pour les appuyer; ces outils sont à la portée des communautés autochtones, des gestionnaires des ressources et des décideurs gouvernementaux et pourraient améliorer la collaboration au sein du secteur forestier. Voici donc ces principes : établir des relations de respect; une grande implication de la communauté; le rapprochement entre le savoir et les systèmes de valeurs; des systèmes de gestion flexibles et globaux et des mesures précises et pertinentes du succès. Bien quoon puisse choisir d'adopter un seul ou une combinaison de ces principes, il serait préférable de les voir comme un processus intégré et progressif auprès de partenaires motivés pour améliorer les processus collaboratifs actuels et en développer de nouveaux. Espérons que les enseignements présentés dans cet article serviront de base à différents groupes d'intervenants afin qu'ils comprennent mieux les besoins des autres et ultimement travaillent plus efficacement à un objectif de coexistence respectueuse et déquité au sein du secteur forestier du Canada.

Mots clés : Autochtones, collaboration, développement, Première Nation, forêt, gestion Autochtone, ressource naturelle, partenariat, planification

\footnotetext{
${ }^{1}$ Faculty of Natural Resources Management, Lakehead University, Thunder Bay, ON, P7B 5E1, *probitai@lakeheadu.ca

${ }^{2}$ Faculty of Graduate Studies, Lakehead University, Thunder Bay, ON, P7B 5E1

${ }^{3}$ Office of the Provost and Vice President (Academic), Lakehead University, Thunder Bay, ON, P7B 5E1
} 


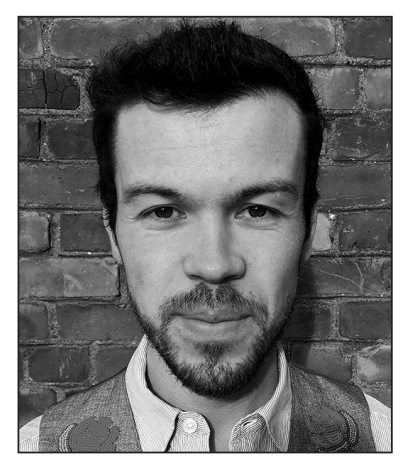

Paul A. Robitaille

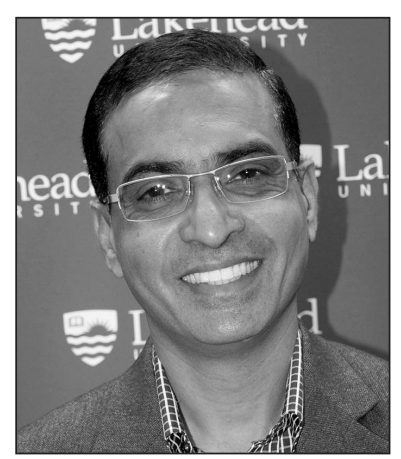

Chander Shahi

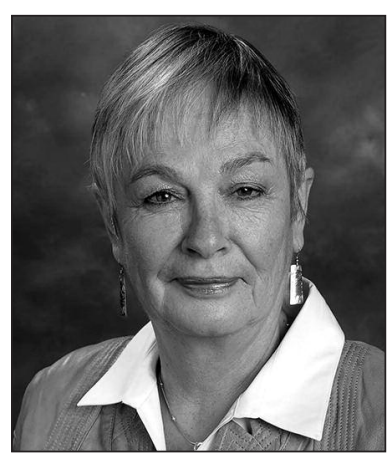

M.A. (Peggy) Smith

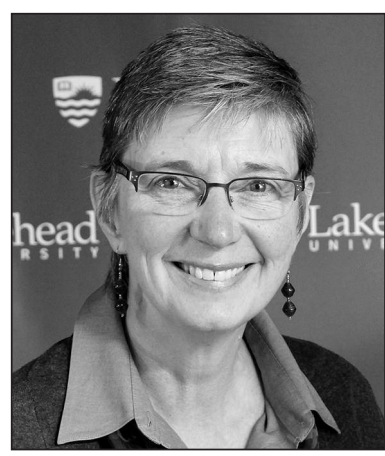

Nancy Luckai

\section{Introduction}

The topic of "aboriginal forestry" has been the focus of significant interest and study in recent years, which has resulted in a growing body of peer-reviewed literature examining the involvement of Indigenous peoples (First Nation, Métis, and Inuit) within Canada's forest resource sector. Far from uniform or static, these roles have evolved over time within the context of ever-changing national (Young and Duinker 1998) and provincial (Griffith et al. 2015) forest policy regimes. These changes have resulted in a large and diverse range of participatory mechanisms being utilized by Indigenous communities across the country. Through an examination of 302 published articles and reports describing current Indigenous participation in forestry in Canada, Wyatt et al. (2013) identified five distinct types of participatory arrangements, with thirty-four different sub-types, including: treaties, agreements and MOUs; management and planning roles; influence on decision-making; forest tenures; and economic roles. Fortier et al. (2013) demonstrated that these approaches were not employed evenly across Canada, or even regionally within particular provinces, which likely reflects the differences in forest policy that exist both across and within individual provinces (e.g., Ontario's Area of the Undertaking versus the Far North). Additionally, rather than participating in the forest sector through only one specific type of arrangement, many Indigenous communities engage in multiple forms of participation simultaneously, highlighting the fact that various participatory mechanisms likely influence the implementation of others (e.g., holding a forest tenure and owning a sawmill), and that each mechanism likely offers different benefits to communities (Fortier et al. 2013). In light of these insights, it has been suggested that government attitudes and policies need to better encourage a diversity of options and arrangements for Indigenous participation in forest resource management and development, rather than a "one-size-fits-all" approach to Indigenous engagement (Wyatt et al. 2013, p. 29).

To further refine our understanding of the subject and of the underlying factors that influence meaningful Indigenous participation in forest resource management, many studies have sought to gain insights into specific arrangements employed within particular communities (e.g., O'Flaherty et al. 2008, Bull et al. 2014, Beaudoin et al. 2015) or the factors that contribute to the success of individual participatory mechanisms (e.g., Fraser et al. 2006, Berkes 2010, Takeda and Ropke 2010). Additional studies have examined the concept of "aboriginal forestry" in a broader, more abstract manner, attempting to define its central characteristics and offering methods of evaluating how effectively it is being achieved (e.g., Parsons and Prest 2003, Wyatt 2008). While such studies are of immense theoretical value and contribute greatly to our understanding of the subject, their focus on either casespecific processes or broad, philosophical discussions may ultimately limit their value to forest managers who are required to develop comprehensive forest management and community engagement strategies, drawing on a variety of disparate tools and engagement techniques.

This current gap within the literature has been discussed in many recent peer-reviewed studies which have expressed that while the need for meaningful Indigenous participation in forest management is well-established, little work has been done to articulate the common set of factors that are necessary to ensure its successful achievement, regardless of the particular mechanism through which the community decides to engage (e.g., Booth 1998). Indeed, there remains a strong need to elaborate on how meaningful Indigenous participation can be achieved (Klenk et al. 2013).

As Wyatt et al. (2013) suggest, a useful starting point may be to examine forest resource development as a social phenomenon occurring between resource managers, policy makers and Indigenous communities. Using this perspective, there is a strong need to identify requisites for successful relationships, which can then be used to develop tools, guidelines and methods for achieving effective joint management (Sherry 2005). As proposed by McGregor (2002), one potential method to achieve this objective is to examine approaches that participants have deemed "successful" or "unsuccessful" and derive the common sets of factors that contributed to each outcome.

Through a systematic review of recent peer-reviewed literature, this article aims to fill the current knowledge gap by identifying principles and practical advice that can be adopted by resource managers, policy makers and Indigenous communities wishing to engage in forest resource management or development on more equitable and mutually-beneficial terms. Through understanding and implementing these lessons, Indigenous and non-Indigenous actors can ultimately begin to work more effectively toward "the development of a 'co-existence' relationship," (McGregor 2011, p. 307) and toward providing Indigenous communities with the tools they need to successfully identify and take advantage of the opportunities facing them within Canada's forest sector (Nikolakis and Nelson 2015). 


\section{Methodology}

\section{Systematic Literature Review}

Guided by the research question, "What practical steps can be taken to facilitate more effective Indigenous-non-Indigenous collaboration in Canada's forest resource sector?" a threephase systematic review (Berrang-Ford et al. 2011) of peerreviewed literature was conducted. The first phase began on February 17, 2016, when a keyword search of the Web of Science online database was conducted. Given the scope of this review paper, and recognizing the broad nomenclature used to describe Indigenous participation in Canada's forest resource sector, the keyword search utilized the following search terms: "aboriginal," "first nation*," "indigenous," "forest*," "natural resource,", "plan*," "consult ${ }^{*}$," and "manage.". Expanders (i.e. " ")") were applied to many of the search terms to reflect the diversity of permutations that could exist within the literature (e.g., consult, consultant, consultation). Following this initial search, which yielded 2954 articles, exclusion criteria were applied to limit search results to studies conducted within Canada, published in the English language, having "article" as the document type, and covering the subject areas of forestry, ecology, environmental studies, environmental sciences, sociology, anthropology, political science, planning development, social sciences interdisciplinary, or economics. The 236 articles retrieved during the first phase were then subjected to a title and abstract review to determine whether each would be included in the final list of articles to receive comprehensive review and analysis. During this phase, articles were excluded which were not directly related to Indigenous community participation in management, planning or consultation processes within Canada's forest sector. This process resulted in a final bibliography of 77 articles. In the third phase, a systematic document review was conducted. A questionnaire was developed to standardize this review process, which included identifying each article's publication year, study location, Indigenous partners, purpose, research questions, methodology, results, conclusions, and suggested areas of future research.

\section{Thematic Synthesis}

Following the document review phase, an analysis of the selected articles was conducted using an iterative, inductive (Creswell 2014) thematic synthesis approach (Thomas and Harden 2008). In the first stage of analysis, participatory mechanisms or factors that had been cited as having contributed to either successful or unsuccessful Indigenous participation in Canada's forest sector were manually free coded, using a descriptive, simultaneous coding approach (Saldana 2013). Coded excerpts were then transferred into Microsoft Word for subsequent phases of analysis. In the second stage, descriptive themes were developed by the first author by grouping stage one codes based on their similarities and differences (Thomas and Harden 2008). These descriptive themes were provided to the three review authors for comment and were agreed upon prior to the third stage of analysis. In the third stage, descriptive themes were synthesized into analytical themes, which represented general principles that can be adopted to facilitate more effective Indigenous collaboration in Canada's forest sector. The descriptive themes developed thus became the underlying mechanisms that can be used to support the implementation of the general principles. This process was repeated until analytical themes were sufficiently broad enough to encompass all identified descriptive themes and consensus was reached by the authors on the acceptability of the resulting descriptive and analytical coding framework. It is fully recognized that the processes of coding (Saldana 2013) and thematic synthesis (Thomas and Harden 2008) are inherently subjective and interpretive and that the resulting framework of principles and supporting mechanisms presented in this article represents the conceptualization of the authors alone.

\section{Results}

Five broad principles, with twenty-three supporting mechanisms, emerged from the literature analysis (Table 1). These principles include: building respectful relationships; broad community engagement; bridging knowledge and value systems; flexible and holistic management systems; and, clear and relevant measures of success. Within the following subsections, each principle will be examined in greater detail, with specific focus on: the role of each principle in achieving more meaningful and equitable Indigenous participation in Canada's forest resource sector; factors that have historically prevented each principle from being achieved; and, concrete steps that can be used to help ensure each principle's successful implementation.

\section{Building Respectful Relationships}

Because collaboration within the forest sector is, at its core, a social phenomenon (Wyatt et al. 2013), it follows that building respectful relationships between Indigenous communities, forest managers and government policy makers must serve as a prerequisite for any type of collaborative arrangement or partnership to be successful over the long term. Indeed, the benefits of respectful relationships have been highlighted in numerous peer-reviewed studies. Through a case study of the Wolf Lake First Nation's pursuit of resource-based development initiatives, VanSchie and Haider (2015) note that successful partnerships between First Nations, governments and industry could be used as a tool to not only meet industry's and government's regulatory objectives, but also to advance First Nations' economic, social and ecological agendas. Furthermore, such partnerships can also help to effectively resolve conflicts as they arise (Berkes 2010) as well as facilitate collaborative learning (Fraser et al. 2006) and better understandings of each partner's goals and challenges within forest management (Merkel 2007). Individuals who are directly engaged in these partnerships can later share their experiences with their respective organizations to facilitate cross-cultural adaptive learning networks (Davidson-Hunt 2006).

Despite the importance of this principle, a number of factors have historically served to hinder these relationships from forming, ultimately making it difficult for any type of meaningful collaboration to occur. Of central importance to understanding these relationship breakdowns is what has been described as a jurisdictional "tangle" (Smith 2015, p. 25) or "catch 22" (McGregor 2011, p. 302), whereby Canada's constitution places jurisdiction over lands and resources with the provinces, while responsibility for Indigenous peoples lies with the federal government. As the administrators of forest policy and management regimes, however, the provinces are ultimately responsible for both interpreting and implement- 
Table 1: Principles and supporting mechanisms for developing collaborative relationships in Canada's forest sector

\begin{tabular}{|c|c|c|c|c|c|}
\hline Principle & $\begin{array}{l}\text { Building Respectful } \\
\text { Relationships }\end{array}$ & $\begin{array}{l}\text { Broad Community } \\
\text { Engagement }\end{array}$ & $\begin{array}{l}\text { Bridging Knowledge } \\
\text { and Value Systems }\end{array}$ & $\begin{array}{l}\text { Flexible andHolistic } \\
\text { Management Systems }\end{array}$ & $\begin{array}{l}\text { Clear and Relevant } \\
\text { Measures of Success }\end{array}$ \\
\hline $\begin{array}{l}\text { Supporting } \\
\text { mechanisms }\end{array}$ & $\begin{array}{l}\text { - Recognition of } \\
\text { Aboriginal and treaty } \\
\text { rights (e.g. Smith 1998) } \\
\text { - Understanding biases } \\
\text { and stereotypes (e.g. } \\
\text { Lee and Kant 2006) } \\
\text { - Well-defined and } \\
\text { accepted roles (e.g. } \\
\text { MacKinnon et al. 2001) } \\
\text { - Forums for knowledge } \\
\text { exchange (e.g. Natcher } \\
\text { et al. 2005) }\end{array}$ & $\begin{array}{l}\text { - Targeted engagement } \\
\text { of marginalized } \\
\text { groups (e.g. Reed } \\
\text { 2010) } \\
\text { - Transparent } \\
\text { guidelines for } \\
\text { determining which } \\
\text { individuals are } \\
\text { engaged (e.g. Davis } \\
\text { and Wagner 2003) } \\
\text { - Including individuals } \\
\text { with land-based } \\
\text { experiential knowledge } \\
\text { (e.g. Davidson-Hunt } \\
\text { 2006) } \\
\text { - Culturally-relevant } \\
\text { forms of information } \\
\text { sharing (e.g. Miller } \\
\text { et al. 2010) }\end{array}$ & $\begin{array}{l}\text { - Common definitions } \\
\text { of "values" (e.g. Sapic } \\
\text { et al. 2009) } \\
\text { - Using modern } \\
\text { technology to support } \\
\text { tradition (e.g. } \\
\text { Kayahara and } \\
\text { Armstrong 2015) } \\
\text { - Representing land- } \\
\text { scapes in ways that } \\
\text { communities see them } \\
\text { (e.g. Lewis and } \\
\text { e Sheppard 2006) } \\
\text { - Adequate funding and } \\
\text { support for values } \\
\text { collection (e.g. Mabee } \\
\text { and Hoberg 2004) } \\
\text { - Community control } \\
\text { of information (e.g. } \\
\text { Robinson and Rossa } \\
\text { 1997) }\end{array}$ & $\begin{array}{l}\text { - Incorporating social } \\
\text { and cultural consider- } \\
\text { ations (e.g. Maclean } \\
\text { et al. 2015) } \\
\text { - Understanding } \\
\text { available management } \\
\text { options (e.g. VanSchie } \\
\text { and Haider 2015) } \\
\text { - Accommodating pre- } \\
\text { ferred practices (e.g. } \\
\text { Jacqumain et al. 2012) } \\
\text { - Creating culturally } \\
\text { recognizable landscape } \\
\text { patterns (Lewis 2008) } \\
\text { - Mechanisms to } \\
\text { influence decision } \\
\text { making (e.g. Fortier } \\
\text { et al. 2013) }\end{array}$ & $\begin{array}{l}\text { - Recognizing limita- } \\
\text { tions of current } \\
\text { criteria and indicator } \\
\text { frameworks (e.g. } \\
\text { Natcher et al. 2009) } \\
\text { - Community-derived } \\
\text { criteria and indica- } \\
\text { tors (e.g. Kant and } \\
\text { Brubacher 2008) } \\
\text { - Monitoring at the } \\
\text { finest resolution } \\
\text { possible (e.g. Fraser } \\
\text { et al. 2006) } \\
\text { - Transparent guide- } \\
\text { lines for aggregating } \\
\text { data across spatial } \\
\text { scales (e.g. Karjala } \\
\text { et al. 2004) } \\
\text { - Forest certification as } \\
\text { tool in partnerships } \\
\text { (e.g. Smith 1998) }\end{array}$ \\
\hline
\end{tabular}

ing constitutionally-protected Aboriginal and treaty rights as they pertain to forest management. To exacerbate this issue, individuals commonly tasked with operationalizing these interpretations, such as industrial forest managers and the auditors who inspect them, may be unclear about their responsibilities related to the application of Aboriginal and treaty rights within forest management and planning, which can make it difficult to meet their formal regulatory requirements (Teitelbaum and Wyatt 2013). This complex interplay between government and industry roles in engaging with Indigenous peoples can serve to slow or even stall any progress in building successful relationships between the groups. Ultimately, as Smith (2015) contends, the only path that can lead to the meaningful reconciliation of Indigenous and non-Indigenous interests in forest management is ensuring that Indigenous and treaty rights are incorporated fully into government forest policy regimes. Within the context of Manitoba's forest policy regime, Griffith et al. (2015) contend that until new actors, such as Indigenous peoples, are provided meaningful opportunities to participate in legislative development, existing actors, particularly provincial governments and forest industry representatives, will continue to exert their influence and unilaterally shape forest policy.

On a more practical level, the combination of Canada's jurisdictional framework and ineffective forest policy regimes has resulted in "command-and-control" forms of top-down forest governance, which are often rejected by Indigenous communities and regarded as inappropriate and counter-productive for learning and developing agreements (Greskiw and Innes 2008, p. 1941). Indigenous community representatives often have little formal training in forest management, which results in even greater power imbalances in resource governance and, ultimately, a diminished ability to derive meaningful community benefits from development (Wyatt et al. 2015). To compound this issue, limitations imposed on First
Nations governance structures by the Indian Act make it difficult to develop the appropriate institutional structures necessary to counteract these imbalances (Nikolakis and Nelson 2015). As a consequence, Indigenous communities may eventually be forced to "play within the rules" of state-sponsored governance arrangements, simply to access the tools and benefits communities need to participate in the forest sector (Stevenson 2006, p. 172).

Recent literature has provided a variety of mechanisms that can be employed to help counteract the effects of systemic power imbalances and aid in the formation of more respectful partnerships within the forest sector. As a positive initial step, any forest manager or community wishing to engage in some form of partnership should endeavour to understand their own values and biases, as well as their perceptions of the other groups with which they hope to engage. In studying the factors that help facilitate common understandings and stronger relationships in forest governance, both Lee and Kant (2006) and Kumar and Kant (2007) demonstrated that, while there are some differences in the ways that Indigenous people, forest industry groups and governments view and approach forest resource development, many strong similarities exist. Additionally, in studying how participants perceived each other's values, it was demonstrated that perceptions are often based on stereotypical views of particular groups, which do not often reflect the true views held by individuals within that group (Lee and Kant 2006). In light of these insights, it becomes clear that groups must work to build strong relationships and use them to develop management strategies that meet the objectives of all parties, rather than imposing systems and practices that the dominant group finds acceptable and expedient (Kayahara and Armstrong 2015). Using the example of vegetation management, Wyatt et al. (2011b) reinforce this notion by asserting that, since no universal Indigenous perspective exists, forest 
managers must consider how their values and perceptions compare to the broader public's and begin to work more collaboratively with communities to develop mutually-acceptable strategies that meet each party's objectives and concerns. Studying working group effectiveness in forest co-management, Natcher et al. (2005) add that success in partnerships often lies in a group's ability to embrace differences in knowledge and cultural experience and value the contributions of others. This acceptance ultimately helps to build and strengthen relationships by facilitating the emergence of group identity and trust among individuals and groups.

Once forest managers acknowledge their biases and fully accept the need to recognize and respect Aboriginal rights, interests and perspectives, forums can be created that facilitate meaningful knowledge exchange and provide a venue for a genuine relationship to manifest itself. In creating such forums, the literature offers a variety of suggestions that should be incorporated-or at the very least considered-to help ensure that they remain open, transparent, collaborative and inclusive spaces (Hvenegaard et al. 2015), and allow for meaningful dialogue while accepting that differences in viewpoints will inevitably occur between partnering groups. One such prerequisite for any cross-cultural relationships is the need for each group to have well-defined and accepted roles within the collaborative arrangement and to be forthright and transparent about their interests and objectives in the partnership (MacKinnon et al. 2001), with clear criteria to determine whether each group is achieving its desired outcomes (Mabee and Hoberg 2006). Through the recognition and respect of each group's unique needs, as well as shared values within the group, disparate actors can help to form a stronger team dynamic and ultimately work to more effectively achieve a shared vision for future action (Berkes 2010) and overcome disagreements and crises as they arise (Greskiw and Innes 2008). In doing so, groups can collectively translate shared values and vision into mutually-beneficial outcomes, which will serve to further strengthen trust and confidence in the group, support reciprocity among members (Hvenegaard et al. 2015) and provide further incentives to continue to invest in the relationship (Berkes 2010).

These collaborative arrangements and the governance processes that support them need to be viewed as flexible structures, "with untold possibilities and permutations" (Caine 2013, p. 354) that are able to evolve to meet the current needs of the group or the individual actors within them (Hvenegaard et al. 2015). In many instances this will not only require the initial baseline information from independent and unbiased third-party sources (Fraser et al. 2006) and sufficient financial resources to establish such collaborative processes (Hvenegaard et al. 2015), but also ongoing leadership (Treseder and Krogman 1999) and political support (Weber et al. 2012), including champions (Hvenegaard et al. 2015) and technical support staff (Beaudoin et al. 2015) within each organization to maintain an ongoing understanding of, and commitment to, the partnership agreement.

Once collaborative relationships, forums for knowledge exchange and decision-making processes are established, it may be useful to solidify them through more formalized arrangements, such as memoranda of understanding (Grainger et al. 2006), that can be incorporated into co-management structures, as this step can help bring increased clarity and transparency to the relationship (Merkel 2007). That said, as Klenk et al. (2013) emphasize through their study of the Prince Albert Model Forest, unofficial modes of dialogue should always be maintained, as they can help to build and maintain better understandings of partners' perspectives and continue to support group objectives.

Finally, in building meaningful relationships, partners must always remain cognizant that trust and confidence among groups takes time to build (Cheveau et al. 2008), especially in the face of so many historical and systemic issues. Similarly, the devolution of forest governance to locally-based collaborative co-management structures will also take time (Berkes 2010). However, once such arrangements and the relationships that underlie them are fully established, opportunities for more meaningful Indigenous community engagement in forest management can ultimately be achieved.

\section{Broad Community Engagement}

Despite the imperative to incorporate a wide range of values and perspectives into forest management planning, a growing body of evidence suggests that attempts to engage communities in meaningful forms of dialogue may often fall short of this objective. Through a review of forest sector advisory committees across Canada for example, Reed (2010) concluded that only $7 \%$ of participants self-identified as Indigenous, and that other demographic groups such as lower socioeconomic classes and women were also vastly underrepresented in forest governance, with the latter representing only $18.7 \%$ of board members. When Indigenous communities are represented, it is predominately by elected community leadership (Wyatt et al. 2010) or economic interests, leading both Reed (2010) and Booth (1998) to conclude that processes need to be developed that engage the entire community, rather than being dominated by community elites. Through a review of Model Forest governance, Klenk et al. (2013) have echoed this sentiment and contend that it is very difficult to adequately represent a diverse community through only a single representative, and that without mechanisms to ensure responsiveness to community needs, there is a risk that certain groups may be over or under-represented in decision-making.

To further illustrate this need, recent studies have demonstrated that the interests and perspectives of individual community members may vary considerably from the community leadership tasked with making forestry-related decisions. Miller and Davidson-Hunt (2013) for example, have acknowledged that the worldviews of Indigenous youth may vary considerably from older generations. Stevenson (2006) has echoed this insight, observing that the use of the term "conservation" is much more prevalent among Indigenous youth than it is among Elders. Similarly, Lewis and Sheppard (2006) have demonstrated that generational differences exist in the ways that youth and Elders interact with, and accept, various support tools, such as maps and landscape visualization software that are used in forest resource decision-making. Because traditional outcomes of forest development, such as capacity-building arrangements (Wyatt et al. 2013), employment opportunities (Zurba and Trimble 2014), or cultural-retention initiatives (Booth and Muir 2013) are often targeted towards Indigenous youth, these differences in perspectives may result in such opportunities being unbeneficial or undesirable to youth, as they are created on youths' behalf, but without their direct input. Fur- 
thermore, any collaborative arrangements developed without the direct input of youth run the risk of becoming irrelevant over time, as younger generations enter community leadership roles (Zurba and Trimble 2014).

While Indigenous youth offer a strong illustrative example, the need for distinct consultation has been demonstrated for other demographic groups as well. Kumar and Kant (2007), for example, have demonstrated that rises in income may result in changes to personal forest-related value systems. Wyatt et al. (2010) have also suggested that the formality of the language used in community engagement meetings can often serve as a barrier for Indigenous participation, in general, deterring the inclusion of a broad range of participants, including Indigenous women, and the interests they represent. Given the current "interest-based," economically-driven model of inclusion in many current systems, those with predominately social interests are unlikely to be considered stakeholders and, therefore, to participate (Reed 2010, p. 47). Wyatt et al. (2010) have suggested that while the general population is currently typically only engaged regarding specific topics under consideration, community members will participate in forest management planning and decision-making when the opportunity is provided. The question, therefore, becomes: How can we encourage and facilitate a broader range of participation in Indigenous communities?

The current literature offers a variety of mechanisms and insights that can be helpful in ensuring that the objective of engaging and incorporating a broad range of community interests and perspectives into forest resource governance is successfully achieved. The first step is to identify the individuals who represent unique perspectives or interests in forest management within the community. While many tools are available to accomplish this objective, a logical initial approach may be to map flow diagrams of the environmental pathways affected by forest management, as such mapping will enable the identification of the stakeholder groups that will likely be affected the most by resource development (Fraser et al. 2006). However, while being directly affected by the effects of forest management is certainly grounds for engagement in planning and decision-making, it is not the only environment-related factor that should be considered. Through working with Anishinaabe First Nations in northwestern Ontario, Davidson-Hunt (2006) has suggested that, through lived experience, individuals become more attuned to the signs and signals of the land, which allow them to identify what is normal or mundane and provide a baseline with which to measure abnormal change. Within the Anishinaabe worldview, these skills represent responsibilities gifted by the Creator that cannot be delegated to other persons or represented through abstract knowledge (Davidson-Hunt 2006). Consequently, these individuals must also be provided with a distinctive role in forest management, as they can provide invaluable insights which can support the interests of other affected stakeholders. As Stevenson (2006) adds, when such knowledge holders are not directly engaged in decision-making, there is a large risk of decontextualizing information that cannot be adequately expressed through Western analytical techniques.

More broadly, entire communities can be engaged in open and transparent forms of stakeholder identification, which empowers them to determine the range of values and perspectives they believe should be included and the individuals best suited to represent them. Examining expert selection in the context of traditional knowledge collection, Davis and Wagner (2003) demonstrated that eliciting recommendations from a wide range of community members as to who they believe should be consulted, and using those recommendations to systematically engage respected individuals, yielded a more appropriate and acceptable list of participants than simply assuming that those with the most experience in a subject were best suited to represent community interests. Similarly, in documenting traditional fire-related knowledge, Miller et al. (2010) noted that allowing Elders to identify individuals with extensive and highly-respected knowledge yielded positive results. No matter who is engaged, it is important to ensure that the processes used to identify them are transparent and systematic, so that they remain acceptable and defensible in the eyes of community members and resource managers alike (Davis and Wagner 2003).

Once engaged, forums need to be created where participants feel comfortable sharing and discussing their knowledge and experiences in ways that are meaningful and relevant to them, whether it be through formal discussion or culturally-relevant media, such as artistic representations of knowledge (Miller et al. 2010). Ultimately, such processes that engage a wide range of community interests and perspectives not only serve as the basis for cross-cultural (Mabee and Hoberg 2006) and intergenerational (Miller et al. 2010) learning, but also build trust (Natcher et al. 2005) and foster more effective group decision-making and truly transformational and equitable change (Griffith et al. 2015).

\section{Bridging Knowledge and Value Systems}

As important as it is to identify and reconcile the diversity of values and perspectives within communities, it is equally important to develop and implement mechanisms to bridge the differences in knowledge and value systems that exist between Indigenous and non-Indigenous partners within forest governance structures. Indeed, many studies have suggested that cultural differences in perspectives and worldviews between forest managers and Indigenous peoples often cause these groups to value and prioritize different types of knowledge within forestry-related contexts (O'Flaherty et al. 2008). These differences can become problematic during forest management and planning processes, as the views of minority groups such as Indigenous peoples, may be superseded by those of more dominant actors such as industry or government (Reed 2010). Similarly, numerous researchers have demonstrated that fundamentally different philosophies on human-ecosystem interactions can hinder effective collaboration within culturally-diverse groups (e.g., Smith 2015). As Natcher et al. (2005) contend, non-First Nations often demonstrate individualistic behaviour, valuing economics over the cultural consequences of forest resource development. Conversely, studies conducted in partnership with First Nations from across Canada have clearly demonstrated that Indigenous peoples throughout the country view themselves as partners in sacred relationships with the natural world, which must be maintained through respect, reciprocity and cultural protocols (e.g., Miller and Davidson-Hunt 2013). As a result of such differences in worldviews, each group will ultimately view acceptable harvesting practices in fundamentally different ways (Parsons and Prest 2003). To compound the issue, these differences may also make it difficult to read- 
ily perceive the types of values that hold importance within other belief systems (Castleden et al. 2009), thereby highlighting a need to develop concrete mechanisms to bridge worldviews and develop common understandings.

Traditional land-use and occupancy studies (TLUOS) and traditional knowledge studies are tools that have long been used by Indigenous communities to both codify "knowledge systems" (Davis and Wagner, p. 465) held within communities and convey Indigenous interests and worldviews to nonIndigenous resources managers in ways that are able to be incorporated into Western planning frameworks. Recognizing the value of these tools in bridging knowledge and value systems, many studies have focused on identifying aspects that can lead to their successful development and implementation. As a first-and critical-step, care should be taken to develop common understandings of what each partnering group means by the term "values". As Sapic et al. (2009) explain, Indigenous peoples typically define values as holistic landscape features, incorporating historical, cultural, spiritual, and social components-not simply as physical points on a map. Trappers' cabins, for example, are commonly treated as discrete locational features in conventional forest planning processes and protected using fixed-area buffers. To the Indigenous trappers who use them however, the full value of the cabins may be contingent upon a diverse variety of factors, such as firewood collection, shelter from the wind and the trapline area in its totality, which may not be adequately protected under conventional methods (Sapic et al. 2009). In many cases, the value of such features also lies within the maintenance of specific landscape conditions, including aesthetic attributes (Lewis and Sheppard 2005). Because of these differences in worldviews, narrow definitions found within Western planning frameworks can be confusing, leading to questions such as, "Is value a culture or tradition, or a place where someone goes?" (Sapic et al. 2009, p. 793). It must also be recognized that the very concept of defining values may be antithetical to Indigenous belief systems (Sapic et al. 2009) and that maps alone may not be able to fully express Indigenous knowledge systems that are often oral or non-verbal in nature (O'Flaherty et al. 2008). Therefore, it may be useful to combine land-use maps with more abstract values mapping (Cheveau et al. 2008) and address both how and why values are used in certain ways, as well as the institutions that regulate their use (MacKinnon et al. 2001).

In eliciting such values from Indigenous community members, a variety of techniques have been developed to help better ensure that individuals are able to fully express their knowledge and experiences. Working with the Cheam Band in British Columbia, Lewis and Sheppard (2006) observed that, in many cases, abstract symbolism associated with traditional mapping exercises made it difficult for participants to fully engage in forest planning exercises. Land-based, experiential methods of knowledge and values elicitation, such as field visits and transect walks, may therefore provide a valuable means of gathering culturally-situated forms of information from Indigenous participants (Davidson-Hunt and Berkes 2003). These activities may be supported by the use of innovative techniques such as 3D landscape visualization, which have been demonstrated to meaningfully engage Indigenous participants of all age groups and ultimately, increase community confidence in plans developed using these technique (Lewis and Sheppard 2006). The effectiveness of using visualization technologies and photo-elicitation to gather Indigenous community values in similar studies (e.g., Sapic et al. 2009) can be used to support two general conclusions. Firstly, landscapes should be presented to communities in ways that are meaningful and relevant, reflecting ways that individuals see them (Lewis and Sheppard 2006). Secondly, modern technologies can-and should-be used to support traditional knowledge collection by making such visualizations possible.

Once values are elicited from community members, care should be taken to ensure that each is ground-truthed and accurately mapped for resource management purposes. Not only does this practice help to ensure that values are properly protected (Mabee and Hoberg 2004), but also helps to alleviate the frustration that many resource managers feel regarding the accuracy of values information (MacKinnon et al. 2001). To help ensure that this information is collected and incorporated in ways that are meaningful to both resource managers and Indigenous communities, adequate funding must be provided to undertake the work (Higgins 1999) and independent technical assistance should be made available to communities to help collect and administer data, standardize collection methods, and help underfunded communities with insufficient capacity with best practices, data storage, and confidentiality (MacKinnon et al. 2001). While mutually agreeable methods and processes must eventually be embedded within organizational structures (Rathwell et al. 2015), to the greatest extent possible, values mapping should be conducted locally and led by the community (McGregor 2002), with individuals being compensated for their time and knowledge at a similar rate to other consultants within the forest industry (Merkel 2007).

Additionally, communities must be allowed to retain intellectual property rights for TLUOS information (Robinson and Ross 1997) and the ability to determine what information is shared, and how that sharing takes place (McGregor 2002). This may be difficult however, as in many cases funders may expect access to TLUOS data (MacKinnon et al. 2001). It is important though, to ensure that Indigenous values data remain confidential, to protect communities from encroachment on, damage to, or theft of their values (Mabee and Hoberg 2004) and foster long-lasting relationships based on mutual respect. Indeed, it has been demonstrated that when cultural values are classified and governed by communities, increased efficiency and effectiveness can be achieved in cross-cultural forest management consultations (Mabee and Hoberg 2004).

Finally, values identification and mapping should focus on current, rather than historical, uses (MacKinnon et al. 2001) and be seen as an ongoing process because cultural uses of areas and the values associated with them can evolve over time (Mabee and Hoberg 2004). To accomplish this, technical capacity to conduct these studies should be widespread within communities (MacKinnon et al. 2001) and supported by continued funding for data collection and monitoring (Mabee and Hoberg 2004).

While ultimately it may not be possible to fully integrate two distinctly different knowledge systems, processes that aim to bridge these divides may prove useful in finding agreement on important issues, thereby facilitating productive 
working relationships while respecting the diversity of perspectives that exist within the group (MacKinnon et al. 2001). With such information, derived through broad and comprehensive community engagement, common understandings can be developed between resource managers and Indigenous communities, allowing community members to be more effectively engaged in the entire cycle of forest management planning (Wyatt et al. 2011b). As it is well accepted within the literature that education and "knowledge alone is a poor predictor of acceptability" of forest management practices-as in the case of aerial herbicide spraying-having tools to effectively engage Indigenous communities and elicit community values will ultimately allow resource managers to provide a range of management options to communities, with information about the advantages and disadvantages of each, so that solutions both meet silvicultural objectives and respond to public interests and concerns (Wyatt et al. 2011b, p. 283).

\section{Flexible and Holistic Management Systems}

Once a wide and representative range of values is collected from Indigenous communities in ways that are meaningful to both resource managers and the communities themselves, processes must be developed to translate them into decisionmaking frameworks and forest management plans. This may prove to be a difficult task however, as current forest management systems largely reflect Western worldviews (McGregor 2011) with strong colonial legacies (Bouman et al. 1996), and the assumption that ultimate authority rests with provincial governments (Mabee and Hoberg 2006). Consequently, there remains a strong need to develop processes that incorporate Indigenous values and interests into forest management, as well as provide communities with meaningful opportunities to occupy a more influential role in forestry-related decisionmaking frameworks.

A reasonable first step in accomplishing this objective may be to reconsider the range of values and objectives that managers are willing to address through forest management, because current systems may not adequately reflect the range of social and cultural considerations that Indigenous communities desire. Numerous studies have demonstrated that Indigenous communities routinely express that the limited scope of current forest management plans (Maclean et al. 2015) and the guidelines that inform them (Sapic et al. 2009) may make them inappropriate for protecting the full range of community values and objectives in a holistic and culturallyrelevant manner. Indeed, many communities contend that forest management planning must be expanded to recognize the relationships between the land and Indigenous peoples (Booth 1998), encompassing practices such as the traditional harvesting of both wild game (Booth and Muir 2013) and plants (Lewis 2008), as well as other aspects of the "bush economy" (Robinson and Ross 1997, p. 600). To illustrate this point, through household surveys of the Yukon's Little Salmon Carmacks First Nation, Natcher et al. (2004) demonstrated that $100 \%$ of community households used both berries and trees for a variety of purposes and that non-timber forest products provided both nutritional and medicinal benefits, but also contributed to overall community wellbeing. Furthermore, other forms of resource-based development, such as tourism and outfitter services, may be more in line with community development values (VanSchie and
Haider 2015). Consequently, forest managers must consider the full range of forest products and management options within management plans, rather than simply those of greatest importance to commercial forest operations.

The literature also provides a variety of practices that have been shown to help reconcile current forest management systems with Indigenous values at the operational level, which ultimately allow communities to derive a more holistic range of meaningful benefits. While these practices may serve as a basis for discussion, it must be recognized that since no universal Indigenous perspective on forest management exists (Wyatt et al. 2011b), local communities must always be engaged to flexibly tailor management practices to fit social, cultural and economic conditions. With this consideration in mind, it is worth noting that Indigenous communities often prefer some form of forest management, such as "conservation-forestry" (Nikolakis and Nelson 2015, p. 644) that incorporates community objectives and ecosystem services, to a no-development scenario, as strict conservation may be contrary to Indigenous value systems that promote respectful use and interdependency with the natural world (Lewis and Sheppard 2005). It is imperative, however, to consider that because of the desire for some form of forest management, trade-offs between environmental protection and resource development will inevitably need to occur (Mabee and Hoberg 2004).

In many cases, it has been demonstrated that partial-cut scenarios, with high tree retention, may serve as an acceptable balance between development and values protection, as they help to maintain the intrinsic qualities and naturalness of cultural sites while still allowing communities to derive a range of meaningful economic benefits (Lewis and Sheppard 2005). Indeed, through a study utilizing photo-elicitation to evaluate various forest management scenarios, Lewis (2008) concluded that while most participants were generally comfortable with some form of resource-based economic development, practices that were able to maintain "culturally recognizable forms of land stewardship" (Lewis 2008, p. 57), such as berry patches, were considered most acceptable. Alternatively, concentrating harvesting operations in areas with few or no identified values may also produce a desirable balance between conservation and development, lowering overall harvesting costs by allowing the practice of clearcut silvicultural systems (Jacqmain et al. 2012) and concentrating limited monitoring and protection resources on high-value cultural areas (Beaudoin et al. 2015). This strategy could be paired with intensive silvicultural techniques and enhanced growing stock to increase site productivity and further limit the amount of area managed using less culturally-appropriate methods (VanSchie and Haider 2015).

Concurrently, forest tenures and management policies must allow for more flexibility in harvesting and silvicultural regulations to allow Indigenous communities to derive greater economic benefits while still maintaining biodiversity objectives (Booth 1998). Using mathematical modelling, both Krcmar and VanKooten (2008) and Krcmar et al. (2006) demonstrated that with only a slight relaxation of even-flow, sustained yield policies, Indigenous communities may be able to accelerate harvest levels in early years, allowing them to enhance short-term economic performance and reinvest profits in long-term professional and technical capacity- 
building, without significantly affecting long-term harvest volumes. However, such a strategy would increase annual harvest level variability, which may ultimately negatively affect long-term employment opportunities for community members. Consequently, the example serves to illustrate that, while no single strategy can likely meet all community objectives simultaneously, they provide options for Indigenous communities which can help them make more informed decisions about how to best achieve their long-term visions for community development.

To support the implementation of culturally-relevant forest management practices and ensure that community objectives are being considered and incorporated into planning processes, frameworks must also be developed through which Indigenous communities are able to exert meaningful influence into forestry-related decision-making. This topic has been the focus of significant study within the literature, ranging from theoretical methods of Indigenous participation in the forest sector (Wyatt 2008), to analyses of collaborative arrangements currently employed by Indigenous communities across Canada (e.g., Fortier et al. 2013), to case study reviews of specific collaborative arrangements and the decision-making frameworks that underlie them (e.g., Morton et al. 2012). Collectively, these studies provide insights into a number of factors that should be considered when designing processes that allow for meaningful Indigenous influence into forestry-related decision-making.

While legislative changes would be required for true equality to be achieved (Mabee and Hoberg 2006), willingness of all parties to participate, be open-minded, and committed to working towards deriving mutual benefits (i.e., forming respectful relationships), may serve as a basis for increasing Indigenous influence in forestry-related decisionmaking. With these respectful relationships in place, partners should endeavour to jointly develop continuous management and decision-making processes that allow for participation from all parties throughout the planning cycle (Wyatt et al. 2010). To the greatest extent possible, frameworks should allow all participants to have an equal role in decision-making (Maclean et al. 2015). Even without formal recognition of Aboriginal or treaty rights, or legislative imperatives, commitment to these principles will help to ensure more equitable planning and management processes. Issues may arise, however, when multiple communities-with distinct values and objectives-participate within the same management board. As Mabee and Hoberg (2006) observed within the context of the Gwaii Haanas National Park, although First Nations and government had equal representation on the co-management board, each First Nation had only a single representative, which ultimately perpetuated existing power imbalances.

To counteract such forces, it may therefore be necessary to develop distinct decision-making processes with individual Indigenous communities (Wyatt et al 2010). Such processes must not only allow for discussion of current forest management issues, but also those of a more historic nature, which may still be manifesting themselves within current management systems (Takeda and Ropke 2010). One such process, explored by Morton et al. (2012) in British Columbia, was a two-tiered system in which the public, Indigenous communities and government representatives were all given an opportunity to provide input during the first stage of consul- tation, with direct government to First Nation, nation-tonation, discussions at the second tier. While this two-tiered system increased the total length of the planning process and would have benefitted from more clearly defined and transparent roles for each party as well as public review of tier-two outcomes, overall it was shown to successfully increase Indigenous involvement in forest planning without reducing overall stakeholder approval (Morton et al. 2012). It was therefore suggested that such a process may prove useful in other jurisdictions wishing to provide more meaningful opportunities for Indigenous participation in resourcerelated decision-making.

Finally, it must be recognized that Indigenous participation in forest management planning and decision-making is often constrained by over-extended community leadership (Mabee and Hoberg 2006) and a lack of technical support staff (Greskiw and Innes 2008). It is therefore imperative that adequate financial and human resources are provided to enable Indigenous communities to engage effectively (Wyatt et al. 2010). In the short-term, this could involve employing shared technical advisors to provide consistent and independent information to all parties so that each can approach management decisions from a common understanding (Takeda and Ropke 2010). In the long-term, however, this ultimately involves investing in building widespread professional literacy within all partnering groups (Stevenson 2006), so that every party has the technical and professional capacity necessary to communicate their interests and perspectives effectively and play an equal role in management and decisionmaking (Higgins 1999).

Ultimately, failure to provide opportunities for Indigenous communities to derive satisfactory outcomes may result in the pursuit of more adversarial approaches to inclusion in resource-based decision-making (Wyatt et al. 2015). Processes that respect and incorporate Indigenous values and perspectives into forest management however, have the ability to not only improve the quality of current management practices (Wyatt et al. 2011a) but to develop innovative new practices that are more acceptable to both Indigenous and non-Indigenous forest users who often share many of the same goals (Jacqmain et al. 2012). Once such participatory processes are developed however, there still remains a need to develop additional safeguards to ensure that community values and objectives are truly being met through forest management.

\section{Clear and Relevant Measures of Success}

While criteria and indicator (C\&I) frameworks have become a useful tool for protecting Indigenous values and addressing important issues (Adam and Kneeshaw 2011), recent evidence has suggested that current generic frameworks, such as the Canadian Council of Forest Ministers (CCFM) C\&I, may not be effective for evaluating the impacts on the unique and diverse needs and values of many Indigenous communities. Through household surveys of two First Nations for example, Natcher et al. (2009) observed that community members felt insecure about future access to traditional territories under current tenure frameworks, with growing concerns about their ability to meet their subsistence needs. Similarly, in a review of the John Prince Research Forest, Sherry (2005) concluded that current CCFM C\&I do not adequately meet First 
Nations communities' process needs, including incorporation of way of life, values, beliefs, land ethics and knowledge systems. Likewise, in a study of $13 \mathrm{New}$ Brunswick First Nations, Wyatt et al. (2015) found that current forest management frameworks are largely failing to meet community expectations for deriving forestry-related benefits. Where this ultimately becomes an issue is when communities feel that their ability to meet their needs is becoming restricted, they may opt for more short-term benefits and adopt practices that are unsustainable in the long-term (Natcher et al. 2004). These examples ultimately serve to illustrate Smith's (1998) insight that indicators of sustainable forest management are relevant only when they can be measured at the local level. Almost two decades later, it is clear that there remains a pressing need to develop more locally-relevant evaluative frameworks, such as C\&I that can accurately reflect the values and objectives of individual communities and help ensure that their objectives are achieved.

Fortunately, a large number of case studies exist which offer lessons into the unique components of Indigenous community-based C\&I as well as best practices to ensure that they are able to be integrated into forest management and remain relevant at a number of planning levels. Of primary importance, and for reasons already discussed within this paper, evaluative frameworks must be rooted in a process of broad community engagement, reflecting the diverse range of needs and values that exist within Indigenous communities (Kant and Brubacher 2008). Christensen et al. (2010) suggest that community dialogue should be supported by historical research to help communities better understand the linkages between forests, people, and social change. With that in mind, several elements have been identified within the literature that are known to be underrepresented in current C\&I frameworks, which warrant explicit consideration in community-based discussions. In addition to not fully incorporating Indigenous land ethics and knowledge systems into management systems (Sherry 2005), current C\&I often lack mechanisms to translate TLUOS information into decision-making ability (Robinson and Ross 1997). Additionally, current C\&I often lack mechanisms to adequately address important social aspects of communities, such as capacity building, health and well-being (Sherry 2005), cultural preservation (Gough et al. 2008) and ensuring equal opportunities for all community members to participate in forest management planning (Natcher and Hickey 2002). Ultimately, because of a lack of emphasis on community-specific issues within current C\&I frameworks, forest managers often fail to consider and accommodate these unique community needs (Gough et al. 2008).

To exacerbate this issue, current C\&I frameworks often include and rely on evaluative components that are of little or no relevance to Indigenous communities. Citing C\&I developed in partnership with the Tlazten First Nation in British Columbia, Karjala and Dewhurst (2003) note that community-based indicators exclude some conventional elements, such as evaluating success through measuring timber yields. Similarly, Wyatt et al. (2015) note that in many cases, success in forest management is reported in economic benefits, even though those aspects may be of only relatively minor importance to the communities directly affected by forest management practices. Indeed, through their with work with the
Essipit Innu First Nation, Beaudoin et al. (2016) illustrate that social and cultural benefits are often viewed by Indigenous communities as being equally important to economic outcomes, leading to the conclusion that "forestry is not the finality" (p. 517), but rather a means of achieving more important objectives, such as fostering respectful relationships between humans and the forest. Because of these distinct differences in values and desired benefits, there remains a strong need to incorporate mechanisms into locallyderived C\&I frameworks which allow unique community needs to be reconciled with broader-scale regional, provincial and national objectives.

To assist in this reconciliation of disparate objectives, several studies have suggested that the data used to evaluate forestry success on multiple planning scales should be collected at the finest possible resolution (Fraser et al. 2006), but then made available to inform more broad-scale decisionmaking processes (Gough et al. 2008). Building on this point, Fraser et al. (2006) suggest that this process is facilitated best when there is little separation between decision makers and those who develop evaluative frameworks, and when locallevel data are both collected and aggregated using transparent methodologies (Karjala et al 2004). Additionally, to better facilitate the inclusion of more abstract community values, such as traditional land ethics and worldviews, C\&I should be expanded to include both qualitative and spatial evaluative metrics (Karjala et al. 2004). Using these mutually agreedupon cross-scale and cross-cultural methods, planning partners can engage in meaningful dialogue, while developing effective management plans (Karjala and Dewhurst 2003) that respectfully accommodate differences without necessarily needing to resolve them (O'Flaherty et al. 2008).

In addition to community-based C\&I frameworks, forest certification systems (e.g., FSC, SFI, CSA) are another tool commonly used by Indigenous communities to help achieve their objectives in forest management (Smith 1998). While overall forest certification has been shown to increase Indigenous community satisfaction with forest management practices by more effectively meeting expectations (Kant and Brubacher 2008), auditors often choose to allow continual improvement toward formal company requirements, rather than requiring companies to meet objectives outright (Teitelbaum and Wyatt 2013). Consequently, while Indigenous issues may serve as an important influence within forest certification systems, in many cases they are not ultimately a barrier to companies receiving certifications on their products. In light of this insight, forest certification may be best implemented as a tool used to strengthen existing relationships between Indigenous communities and industry partners, allowing each group to leverage that relationship, and the processes that underlie them, towards deriving mutual benefit (Beaudoin et al. 2015).

Finally, no matter the mechanisms employed to measure success within forest management, clear strategies must be developed to translate community interests and goals into concrete outcomes (Beaudoin et al. 2015). These strategies must also be accompanied by community-led monitoring programs which continually track progress towards achieving the desired goals (Smith 1998) while remaining flexible enough to allow for evolution in response to changing community issues and self-improving feedback (Natcher and 
Hickey 2002). These processes must also be supported by strong governance systems (Trosper $e t$ al. 2008) with sufficient financial and technical resources for initial implementation (Treseder and Krogman 1999) and long-term capacity building (Kant and Brubacher 2008). Additionally, timber allocations must be large enough to ensure that the costs of equipment (Booth and Skelton 2011), forest certification requirements (Smith 1998) and maintaining robust monitoring programs are able to be covered. Ultimately, the combination of community-based measures of success and developing robust means of achieving them will not only enable communities to derive meaningful benefits for their members but also for entire communities-and the individuals within them-to become engaged and empowered by the process itself.

\section{Conclusion}

While the principles and supporting mechanisms presented in this article may be implemented individually or in various combinations to both improve existing collaborative arrangements and develop new ones, it may be useful to conceptualize them as an integrated, incremental process involving any number of motivated partners (Fig. 1). By establishing relationships based on mutual-benefit and respect, collaborators will be better positioned to engage Indigenous communities on meaningful terms, with increased sensitivity to the diversity of interests, values and needs that exist within them. Through this broad community engagement, differences that exist between deeply-held knowledge and value systems can be better understood and reconciled within the planning processes. With such differences reconciled, flexible and holistic management systems, that respond to community needs, can be established and eventually supported by moni-

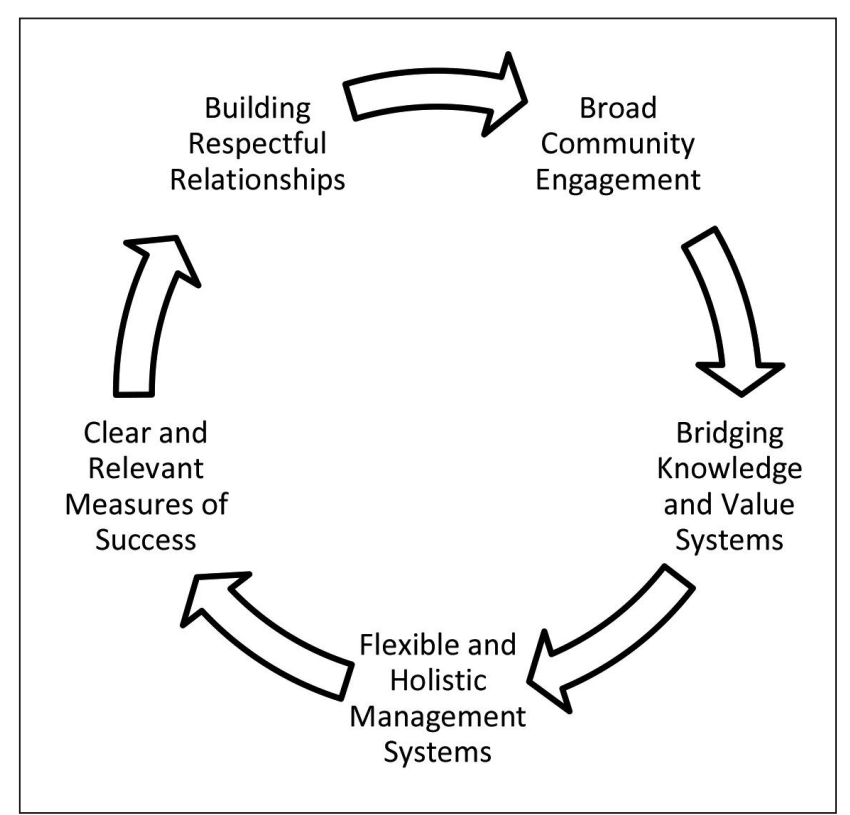

Fig. 1. An integrated principle-based process for developing collaborative partnerships.

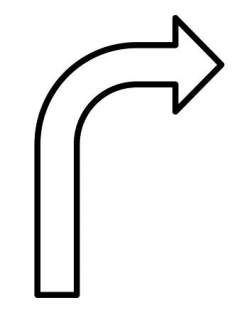

Relevant

Measures of

Success

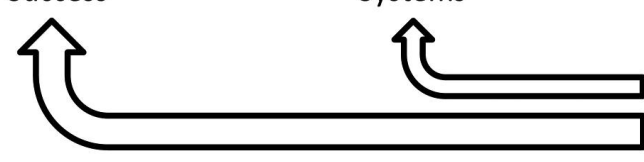

Clear and
Holistic

Management

Systems

Respectful

Relationships

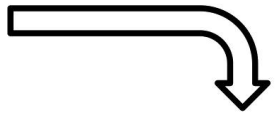

Broad

Community

Engagement

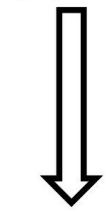

Bridging

Knowledge

and Value

Systems
Fig. 2. Potential feedback cycle between principles.

toring and assessment tools that reflect the needs and objectives of all parties.

It should also be recognized that Fig. 1 represents only a single conceptualization of the relationships that may exist between the identified principles and that in many situations these relationships may be much less tidy or occur in the form of feedback cycles. For example, broad community engagement and bridging knowledge and value systems may be required at multiple stages during the planning process, including during the development of flexible and holistic management systems and in the creation of clear and relevant measures of success (Fig. 2). Techniques such as path analysis (Kant et al. 2014) may be useful for exploring the true diversity of relationships that can potentially exist between the principles.

While future work will certainly help to refine this framework and produce new and innovative tools to support collaborative partnerships, it is hoped that the principles and mechanisms outlined in this paper will serve as a basis for resource managers, policy makers, and Indigenous communities to better understand each other's needs and ultimately work more effectively towards achieving respectful co-existence and equity in Canada's forest sector.

\section{References}

Adam, M.C. and D. Kneeshaw. 2011. Expert opinion on the criteria and indicator process and Aboriginal communities: Are objectives being met? Forest.Chron. 87(3): 358-366. doi: 10.5558/tfc2011-026. Beaudoin, J.M., L. Bouthillier and G. Chiasson. 2015. Growing deep roots: Increasing Aboriginal authority in contemporary forest governance arrangements. Land Use Policy 49: 287-295. doi:10.1016/j.landusepol.2015.08.004.

Beaudoin, J.M., L. Bouthillier, J. Bulkan, H. Nelson, R. Trosper and S. Wyatt. 2016. What does "First Nation deep roots in the forests" mean? Identification of principles and objectives for promoting forest-based development. Can. J. For. Res. 46: 508-519. doi:10.1139/cjfr-2015-0170. 
Berkes, F. 2010. Devolution of environment and resources governance: Trends and future. Environ. Conserv. 37(04): 489-500. doi:10.1017/S037689291000072X.

Berrang-Ford, L., J.D. Ford and J. Paterson. 2011. Are we adapting to climate change? Global Environ. Chang. 21: 25-33. doi: 10.1016/j.gloenvcha.2010.09.012.

Booth, A. L. 1998. Putting "forestry" and "community" into First Nations' resource management. Forest. Chron. 74(3): 347-352. doi:10.5558/tfc74347-3.

Booth, A. L. and N.W. Skelton. 2011. "There's a conflict right there": Integrating indigenous community values into commercial forestry in the Tlazten First Nation. Soc. Natura. Resourc. 24(4) 368-383. doi:10.1080/08941920902755390.

Booth, A. L. and B.R. Muir. 2013. "How far do you have to walk to find peace again?”: A case study of First Nations' operational values for a community forest in Northeast British Columbia, Canada. Nat. Resour. Forum 37(3): 153-166. doi:10.1111/1477-8947.12005.

Bouman, O.T., G. Langen and C.E. Bouman. 1996. Sustainable use of the boreal Prince Albert Model Forest in Saskatchewan. Forest. Chron. 72(1): 63-72. doi: 10.5558/tfc72063-1.

Bull, G., S. Pledger, M. Splittgerber, J. Stephen, A. Pribowo, K. Baker and N. Macleod. 2014. Culturally driven forest management, utilization and values: A Nuxalk First Nations case study. Forest. Chron. 90(5): 620-627. doi: 10.5558/tfc2014-126.

Caine, K. J. 2013. Bourdieu in the north: Practical understanding in natural resource governance. Can. J. Sociol. 38(3): 333-358. Available from: https://ejournals.library.ualberta.ca/index.php/CJS/article/ view/10127/15843 [accessed 16 February 2016].

Castleden, H., T. Garvin and Huu-ay-aht First Nation. 2009. "Hishuk Tsawak" (Everything Is one/connected): A Huu-ay-aht worldview for seeing forestry in British Columbia, Canada. Soc. Nat. Res. 22(9): 789-804. doi:10.1080/08941920802098198.

Cheveau, M., L . Imbeau, P. Drapeau and L. Belanger. 2008. Current status and future directions of traditional ecological knowledge in forest management: A review. Forest. Chron. 84(2): 231-243. doi:10.5558/tfc84231-2.

Christensen, L., N. Krogman and B. Parlee. 2010. A culturally appropriate approach to civic engagement: Addressing forestry and cumulative social impacts in southwest Yukon. Forest. Chron. 86(6): 723-729. doi:10.5558/tfc86723-6.

Creswell, J. 2014. Research design. $4^{\text {th }}$ ed. SAGE Publications Inc., Thousand Oaks, California. 273 p.

Davidson-Hunt, I. J. 2006. Adaptive learning networks: Developing resource management knowledge through social learning forums. Hum. Ecol. 34(4): 593-614. doi:10.1007/s10745-006-9009-1.

Davidson-Hunt, I. J. and F. Berkes. 2003. Learning as you journey: Anishinaabe perception of social-ecological environments and adaptive learning. Conserv. Ecol. 8(1): 5. Available from: http:// www.consecol.org/vol8/iss1/art5.]

Davis, A. and J.R. Wagner. 2003. Who knows? On the importance of identifying "experts" when researching local ecological knowledge. Hum. Ecol. 31(3): 463-489. Available from: http:// resolver.scholarsportal.info/resolve/03007839/v31i0003/463_ wkotioiwrlek.xml [Accessed 16 February 2016].

Fortier, J.F., S. Wyatt, D.C. Natcher, M.A. Smith and M. Hébert. 2013. An inventory of collaborative arrangements between Aboriginal peoples and the Canadian forest sector: Linking policies to diversification in forms of engagement. J. Environ. Manage. 119: 47-55. doi:10.1016/j.jenvman.2013.01.005.

Fraser, E.D.G., A.J. Dougill, W.E. Mabee, M. Reed and P. McAlpine. 2006. Bottom up and top down: Analysis of participatory processes for sustainability indicator identification as a pathway to community empowerment and sustainable environmental management. J. Environ. Manage. 78(2): 114-127. doi:10.1016/j.jenvman. 2005.04.009.
Gough, A. D., J.L. Innes and S.D. Allen. 2008. Development of common indicators of sustainable forest management. Ecol. Indic. 8(5): 425-430. doi:10.1016/j.ecolind.2007.03.001.

Grainger, S., E. Sherry and G. Fondahl. 2006. The John Prince Research Forest: Evolution of a co-management partnership in northern British Columbia. Forest. Chron. 82(4): 484-495. doi: $10.5558 / \mathrm{tfc} 82484-4$.

Greskiw, G. and J.L. Innes. 2008. Comanaging communication crises and opportunities between Northern Secwepemc First Nations and the province of British Columbia. Can. J. For. Res.. 38(7): 1935-1946. doi:10.1139/X08-015.

Griffith, J., A.P. Diduck and J. Tardif. 2015. Manitoba's forest policy regime: Incremental change, concepts, actors and relationships. Forest. Chron. 91(1): 71-83. doi:10.5558/tfc2015-012.

Higgins, C. 1999. Innovative forest practice agreements - What could be done that would be innovative. Forest. Chron. 75(6): 939-942. doi:10.5558/tfc75939-6.

Hvenegaard, G., S. Carr, K. Clark, P. Dunn and T. Olexson. 2015. Promoting sustainable forest management among stakeholders in the Prince Albert Model Forest, Canada. Conservation and Society 13(1): 51-61. doi:10.4103/0972-4923.161222.

Jacqmain, H., L. Bélanger, R. Courtois, C. Dussault, T.M. Beckley, M. Pelletier and S.W. Gull. 2012. Aboriginal forestry: Development of a socioecologically relevant moose habitat management process using local Cree and scientific knowledge in Eeyou Istchee. Can. J. For. Res. 42(4): 631-641. doi:10.1139/x2012-020.

Kant, S. and D. Brubacher. 2008. Aboriginal expectations and perceived effectiveness of forest management practices and forest certification in Ontario. Forest. Chron. 84(3): 378-391. doi:10.5558/ tfc84378-3.

Kant, S., I. Vertinsky, B. Zheng and P. Smith. 2014. Multi-domain subjective wellbeing of two Canadian First Nations communities. World Dev. 64: 140-157. doi:10.1016/j.worlddev.2014.05.023.

Karjala, M. K. and S.M. Dewhurst. 2003. Including aboriginal issues in forest planning: A case study in central interior British Columbia, Canada. Landscape Urban Plan. 64(1): 1-17. doi:10.1016/S0169-2046(02)00196-2.

Karjala, M. K., E.E. Sherry and S.M. Dewhurst. 2004. Criteria and indicators for sustainable forest planning: A framework for recording Aboriginal resource and social values. Forest Policy Econ. 6(2): 95-110. doi:10.1016/S1389-9341(02)00117-X.

Kayahara, G. J. and C.L. Armstrong. 2015. Understanding First Nations rights and perspectives on the use of herbicides in forestry: A case study from northeastern Ontario. Forest. Chron. 91(2): 126-140. doi:10.5558/tfc2015-024.

Klenk, N. L., M.G. Reed, G. Lidestav and J. CarlssonJ. 2013. Models of representation and participation in model forests: Dilemmas and implications for networked forms of environmental governance involving indigenous people: Modes of representation. Environ. Policy Govern. 23(3): 161-176. doi:10.1002/eet.1611.

Krcmar, E. and G.C. van Kooten. 2008. Economic development prospects of forest-dependent communities: Analyzing trade-offs using a compromise-fuzzy programming framework. American Journal of Agricultural Economics 90(4): 1103-1117. doi:10.1111/ j.1467-8276.2008.01149.x.

Krcmar, E., G.C. van Kooten, H. Nelson, I. Vertinsky and J. Webb. 2006. The Little Red River Cree Nation's forest management strategies under a changing forest policy. Forest. Chron. 82(4): 529-537. doi:10.5558/tfc82529-4.

Kumar, S. and S. Kant. 2007. Exploded logit modeling of stakeholders' preferences for multiple forest values. Forest Policy Econ. 9(5): 516-526. doi:10.1016/j.forpol.2006.03.001.

Lee, S. and S. Kant. 2006. Personal and group forest values and perceptions of groups' forest values in northwestern Ontario. Forest. Chron. 82(4): 512-520. doi:10.5558/tfc82512-4. 
Lewis, J. L. 2008. Perceptions of landscape change in a rural British Columbia community. Landscape Urban Plan. 85(1): 49-59. doi:10.1016/j.landurbplan.2007.09.011.

Lewis, J. L. and S.R. Sheppard. 2005. Ancient values, new challenges: Indigenous spiritual perceptions of landscapes and forest management. Soc. Natur. Resour. 18(10): 907-920. doi:10.1080/ 08941920500205533

Lewis, J. L. and S.R. Sheppard. 2006. Culture and communication: Can landscape visualization improve forest management consultation with indigenous communities? Landscape Urban Plan. 77(3): 291-313. doi:10.1016/j.landurbplan.2005.04.004

Mabee, H. S. and G. Hoberg. 2004. Protecting culturally significant areas through watershed planning in Clayoquot Sound. Forest. Chron. 80(2): 229-240. doi: 10.5558/tfc80229-2.

Mabee, H. S. and G. Hoberg. 2006. Equal Partners? Assessing comanagement of forest resources in Clayoquot Sound. Soc. Natur. Resour. 19(10): 875-888. doi:10.1080/08941920600901668.

MacKinnon, L., C. Apentiik and M.P. Robinson. 2001. Revisiting traditional land use and occupancy studies: Relevance and implications for resource management in Alberta. Forest. Chron. 77(3): 479-489. doi:10.5558/tfc77479-3.

Maclean, K., C.J. Robinson and D.C. Natcher. 2015. Consensus building or constructive conflict? Aboriginal discursive strategies to enhance participation in natural resource management in Australia and Canada. Soc. Natur. Resour. 28(2): 197-211. doi:10.1080/ 08941920.2014.928396

McGregor, D. 2002. Indigenous knowledge in sustainable forest management: Community-based approaches achieve greater success. Forest. Chron. 78(6): 833-836. doi:10.5558/tfc78833-6.

McGregor, D. 2011. Aboriginal/non-Aboriginal relations and sustainable forest management in Canada: The influence of the Royal Commission on Aboriginal Peoples. J. Environ. Manage. 92(2): 300-310. doi:10.1016/j.jenvman.2009.09.038.

Merkel, G. 2007. We are all connected: Globalization and community sustainability in the boreal forest, an Aboriginal perspective. Forest. Chron. 83(3): 362-366. doi:10.5558/tfc83362-3.

Miller, A.M. and I.J. Davidson-Hunt. 2013. Agency and resilience: Teachings of Pikangikum First Nation Elders, Northwestern Ontario [online]. Ecol. Soc. 18(3). doi:10.5751/ES-05665-180309.

Miller, A.M., I.J. Davidson-Hunt and P. Peters. 2010. Talking about fire: Pikangikum First Nation elders guiding fire management. Can. J. For. Res. 40(12): 2290-2301. doi:10.1139/X10-177.

Morton, C., T.I. Gunton and J.C. Day. 2012. Engaging aboriginal populations in collaborative planning: an evaluation of a two-tiered collaborative planning model for land and resource management. J. Environ. Plan. Manage. 55(4): 507-523. doi:10.1080/ 09640568.2011.613592.

Natcher, D.C. and C.G. Hickey. 2002. Putting the community back into community-based resource management: A criteria and indicators approach to sustainability. Hum. Organ. 61(4): 350-363. Available from: http://ezproxy.lakeheadu.ca/login?url=http://search.proquest.com/docview/201159555?accountid=11956 [Accessed 16 February 2016].

Natcher, D.C., C.G. Hickey and S. Davis. 2004. The political ecology of Yukon forestry: Managing the forest as if people mattered. Int J. Sustain. Dev. World Ecol. 11(4): 343-355. doi:10.1080/ 13504500409469838 .

Natcher, D.C., S. Davis and C.G. Hickey. 2005. Co-management: Managing relationships, not resources. Hum. Organ. 64(3): 240-250. Available from: http://search.proquest.com/docview/ 201168401/fulltextPDF/891A7711AA6D486EPQ/5?accountid=11956 [Accessed 16 February 2016].

Natcher, D.C., C.G. Hickey, M. Nelson and S. Davis. 2009. Implications of tenure insecurity for Aboriginal land use in Canada. Hum. Organ. 68(3): 245-257. Available from: http://search.proquest.com/ docview/201174377/fulltextPDF/42CC2EE27D8B4BD0PQ/3?acco untid=11956 [Accessed 16 February 2016]
Nikolakis, W. and H. Nelson. 2015. To log or not to log? How forestry fits with the goals of First Nations in British Columbia. Can. J. For. Res. 45(6): 639-646. doi:10.1139/cjfr-2014-0349.

O'Flaherty, R.M., I.J. Davidson-Hunt and M. Manseau. 2008. Indigenous knowledge and values in planning for sustainable forestry: Pikangikum First Nation and the Whitefeather Forest Initiative [online]. Ecol. Soc. 13(1): 6. Available from: http://www.ecologyandsociety.org/vol13/iss1/art6/ [Accessed 16 February 2016].

Parsons, R. and G. Prest. 2003. Aboriginal forestry in Canada. Forest. Chron. 79(4): 779-784. doi:10.5558/tfc79779-4.

Rathwell, K. J., D. Armitage and F. Berkes. 2015. Bridging knowledge systems to enhance governance of the environmental commons: A typology of settings. Int. J. Commons 9(2): 851-880. doi: 10.18352/ijc.584.

Reed, M.G. 2010. Guess who's (not) coming for dinner: Expanding the terms of public involvement in sustainable forest management. Scand. J. For. Res. 25(9): 45-54. doi:10.1080/02827581.2010.506785. Robinson, M.P. and M.M. Ross. 1997. Traditional land use and occupancy studies and their impact on forest planning and management in Alberta. Forest. Chron. 73(5): 596-605. doi:10.5558/ tfc73596-5.

Saldana, J. 2013. The coding manual for qualitative researchers. 2nd edition. SAGE Publications Inc., Thousand Oaks, California. 303 p. Sapic, T., U. Runesson and M.A. Smith. 2009. Views of Aboriginal People in Northern Ontario on Ontario's approach to Aboriginal values in forest management planning. Forest. Chron. 85(5): 789-801. doi:10.5558/tfc85789-5.

Sherry, E. 2005. Local-level criteria and indicators: An Aboriginal perspective on sustainable forest management. Forestry 78(5): 513-539. doi:10.1093/forestry/cpi048.

Smith, M.A. 1998. Aboriginal and treaty rights and Aboriginal participation: Essential elements of sustainable forest management. Forest. Chron. 74(3): 327-333. doi:10.5558/tfc74327-3.

Smith, M.A. 2015. A Reflection on First Nations in their Boreal Homelands in Ontario: Between a Rock and a Caribou. Conserv. Soc. 13(1): 23. doi:10.4103/0972-4923.161214.

Stevenson, M.G. 2006. The possibility of difference: Rethinking comanagement. Hum. Organ. 65(2): 167-180. Available from: http://search.proquest.com/docview/201170470/fulltextPDF/ 51114F09530C45B2PQ/7?accountid=11956 [Accessed 16 February 2016].

Takeda, L. and I. Røpke. 2010. Power and contestation in collaborative ecosystem-based management: The case of Haida Gwaii. Ecolog. Econ. 70(2): 178-188. doi:10.1016/j.ecolecon.2010.02.007.

Teitelbaum, S. and S. Wyatt. 2013. Is forest certification delivering on First Nation issues? The effectiveness of the FSC standard in advancing First Nations' rights in the boreal forests of Ontario and Quebec, Canada. Forest Policy Econ. 27: 23-33. doi:10.1016/j.forpol.2012.09.014.

Thomas, J. and A. Harden. 2008. Methods for the thematic synthesis of qualitative research in systematic reviews. BMC Medical Research Methodology 8(45): 10. doi: 10.1186/1471-2288-8-45.

Treseder, L. and N.T. Krogman. 1999. Features of First Nation forest management institutions and implications for sustainability. Forest. Chron. 75(5): 793-798. doi:10.5558/tfc75793-5.

Trosper, R., H. Nelson, G. Hoberg, M.A. Smith and W. Nikolakis. 2008. Institutional determinants of profitable commercial forestry enterprises among First Nations in Canada. Can. J. For. Res. 38(2): 226-238. doi:10.1139/X07-167.

VanSchie, R. and W. Haider. 2015. Indigenous-based approaches to territorial conservation: A case study of the Algonquin Nation of Wolf Lake. Conserv. Soc. 13(1): 72-83. doi:10.4103/0972-4923. 161225.

Weber, M., N. Krogman and T. Antoniuk. 2012. Cumulative effects assessment: Linking social, ecological, and governance dimensions. Ecol. Soc. 17(2): 22. doi:10.5751/ES-04597-170222. 
Wyatt, S. 2008. First Nations, forest lands, and "aboriginal forestry" in Canada: From exclusion to co-management and beyond. Can. J. For. Res. 38(2): 171-180. doi:10.1139/X07-214.

Wyatt, S., J.F. Fortier and C. Martineau-Delisle. 2010. First Nations' involvement in forest governance in Quebec: The place for distinct consultation processes. Forest. Chron. 86(6): 730-741. doi:10.5558/tfc86730-6.

Wyatt, S., J.F. Fortier, D. Natcher, M.A. Smith and M. Hébert. 2013. Collaboration between Aboriginal peoples and the Canadian forest sector: A typology of arrangements for establishing control and determining benefits of forestlands. J. Environ. Manage. 115: 21-31. doi:10.1016/j.jenvman.2012.10.038.

Wyatt, S., M. Kessels and F. van Laerhoven. 2015. Indigenous peoples' expectations for forestry in New Brunswick: Are rights enough? Soc. Natur. Resour. 28(6): 625-640. doi:10.1080/ 08941920.2014.970735.
Wyatt, S., S. Merrill and D. Natcher. 2011a. Ecosystem management and forestry planning in Labrador: how does Aboriginal involvement affect management plans? Can. J. For. Res. 41(11): 2247-2258. doi:10.1139/x11-126.

Wyatt, S., M.H. Rousseau, S. Nadeau, N. Thiffault and L. Guay. 2011b. Social concerns, risk and the acceptability of forest vegetation management alternatives: Insights for managers. Forest. Chron. 87(2): 274-289. doi:10.5558/tfc2011-014.

Young, J.L. and P.N. Duinker. 1998. Canada's national forest strategies: A comparative analysis. Forest. Chron. 74(5): 683-693. doi:10.5558/tfc74683-5.

Zurba, M. and M. Trimble. 2014. Youth as the inheritors of collaboration: Crises and factors that influence participation of the next generation in natural resource management. Environ. Sci. Policy 42: 78-87. doi:10.1016/j.envsci.20. 